\title{
Exploring the spatial patterns of fire density in Southern Europe using Geographically Weighted Regression
}

\author{
Sandra Oliveira ${ }^{\mathrm{a}, \mathrm{b}, *}$, José M.C. Pereira ${ }^{\mathrm{a}}$, Jesús San-Miguel-Ayanz ${ }^{\mathrm{c}}$, Luciano Lourenço ${ }^{\mathrm{b}}$ \\ ${ }^{\text {a }}$ Forest Research Centre, School of Agriculture, University of Lisbon, Tapada da Ajuda, 1349-017 Lisbon, Portugal \\ ${ }^{\mathrm{b}}$ Centre for Scientific Research on Forest Fires, University of Coimbra, Aeródromo da Lousã, Chã do Freixo, 3200-395 Lousã, Portugal \\ ${ }^{\mathrm{c}}$ Institute for Environment and Sustainability, Joint Research Centre, European Commission, Via E. Fermi 2749, 21027 Ispra, VA, Italy
}

Keywords:

Fire density

Spatial patterns

Driving factors

South European regions

Geographically Weighted Regression

\begin{abstract}
A B S T R A C T
The spatial patterns of fire occurrence were analyzed in two regions of Southern Europe, focusing on the long-term factors that influence fire distribution. The relationship between fire occurrence and the physical and anthropogenic variables collected was investigated with Geographically Weighted Regression (GWR) and the results were compared with Ordinary Least Squares (OLS). Local patterns of the significant variables were explored and a strong spatial variability of their explanatory power was revealed. Climate (precipitation), livestock and land cover (shrubland) were found to be significant in both regions, although in particular areas and to different extents. Regarding model performance, GWR showed an improvement over OLS in both regions.

The investigation of the spatial variation in the importance of the main drivers over a broad study area, gives a valuable contribution to the improvement of fire management and prevention strategies, adjusted to the particular conditions of different areas.
\end{abstract}

(c) 2014 Elsevier Ltd. All rights reserved.

\section{Introduction}

Wildland fire is a widespread event that affects many regions of the world (Bowman et al., 2009; Dwyer, Pinnock, Gregoire, \& Pereira, 2000; FAO, 2010; Flannigan, Krawchuk, de Groot, Wotton, \& Gowman, 2009; Pechony \& Shindell, 2010). Although the occurrence of fires largely depends on local factors, such as vegetation cover and land use (Dwyer et al., 2000; Sebastián-López, Salvador-Civil, Gonzalo-Jiménez, \& San-Miguel-Ayanz, 2008), their impacts are evident also at global scale, when considering atmospheric emissions, land cover change or ecosystem functions and services (Carvalho et al., 2010; Pechony \& Shindell, 2010; Sebastián-López et al., 2008). This global dimension of fires and the need to understand the complex interaction between factors that are not confined to a restricted geographical area, require the assessment of fire occurrence also at regional, continental or global scales (Chuvieco, Giglio, \& Justice, 2008; Sá et al., 2011; Sebastián-López et al., 2008).

From a long-term perspective, fire occurrence is assessed considering the average conditions during a certain period of time, in relation to those factors which remain stable for at least one fire

\footnotetext{
* Corresponding author. Centre for Scientific Research on Forest Fires, University of Coimbra, Aeródromo da Lousã, Chã do Freixo, 3200-395 Lousã, Portugal. Tel.: +351912856 744 .

E-mail address: sisoliveira@gmail.com (S. Oliveira).
}

season, such as topography and roads (Jappiot, Gonzalez-Olabarria, Lampin-Maillet, \& Borgniet, 2009; San-Miguel-Ayanz et al., 2003). The long-term assessment is suitable to investigate the structural factors that affect the fire proneness of an area, assisting in the definition of prevention strategies and the allocation of fire resources prior to the start of the main fire season (Oliveira, Oehler, San-MiguelAyanz, Camia, \& Pereira, 2012; San-Miguel-Ayanz et al., 2003).

At the European level, an extraordinary effort has been made in the last decades to compile reliable information on the fire events that affect many countries (Camia, Houston, \& San-Miguel-Ayanz, 2010; San-Miguel-Ayanz et al., 2012), to assist in fire prevention and in support of policy-making. Statistics reveal that more than 80,000 fires occur on average a year in Europe, which burn over 500,000 ha of land (European Commission [EC], 2012) and cause extensive damage. The factors that influence fire occurrence differ among European countries and regions, as a result of the diversity of biogeographical features, the physical and anthropogenic conditions across the continent, and due to the fire prevention policies and fire suppression techniques applied at national or local levels (Ganteaume et al., 2013; Montiel \& San-Miguel-Ayanz, 2009; Montiel-Molina, 2012; Roekaerts, 2002). Southern Europe, particularly the western countries, where Mediterranean-type climate and vegetation prevail, is the most affected region (Konstantinidis, Tsiourlis, \& Galatsidas, 2005; San-Miguel-Ayanz \& Camia, 2009; San-Miguel-Ayanz et al., 2009). Furthermore, these trends in fire 
occurrence are expected to be amplified due to ongoing land use and climatic changes, which could cause a substantial increase in the fire-proneness of certain areas and in fire severity, even where fires are currently less relevant (Flannigan et al., 2013; Flannigan, Krawchuk, de Groot, Wotton, \& Gowman, 2009; Lindner et al., 2010; Moreira et al., 2011).

Understanding the spatial distribution of fires, its causes and impacts in relation to the specific characteristics of the places where they occur, is crucial for the implementation of efficient strategies of fire prevention and wildland management. The main purpose of this study is, therefore, to contribute to the investigation of the spatial patterns of fire distribution (number of fires) in Southern Europe and uncover the influence of the most important structural factors that drive fire occurrence in the region, with the following objectives:

i) Analyze the spatial variability of fire occurrence in Southern Europe

ii) Identify the main factors that influence fire occurrence across Southern European countries

iii) Assess the consistency of the explanatory power of the variables throughout the study area, exploring the local and regional variations of their significance

Several methods exist to explore the interactions between spatial drivers and fire occurrence; regression methods have been widely used, such as linear and logistic regression (Chuvieco et al., 2010; Oliveira et al., 2012; Sebastián-López et al., 2008) and classification and regression trees (Amatulli, Rodrigues, Trombetti, \& Lovreglio, 2006; Archibald, Roy, van Wilgen, \& Scholes, 2009; Oliveira et al., 2012). These methods focus on the global picture and follow the assumption of spatial stationarity, which is often violated in realworld situations (Koutsias, Martínez-Fernández, \& Allgöwer, 2010; Sá et al., 2011). In broad areas, the level of importance of the variables in explaining fire occurrence is, most likely, not homogeneous throughout the entire study domain (Archibald et al., 2009; Ganteaume et al., 2013). Previous studies suggest that fire assessment models can greatly benefit from the use of analytical methods that capture the spatial attributes of the phenomenon being studied (Koutsias, Martínez, Chuvieco, \& Allgöwer, 2005; Koutsias et al., 2010; Kupfer \& Farris, 2006; Sá et al., 2011). Geographically Weighted Regression (GWR) (Fotheringham, Brunsdon, \& Charlton, 2002) has been applied in the investigation of fire activity at large scale, namely in Mediterranean Europe (Koutsias et al., 2005, 2010) and in sub-Saharan Africa (Sá et al., 2011). GWR allows for regression coefficients to vary for individual locations, capturing the effects of non-stationarity and revealing variations in the importance of the variables across the study area, focusing particularly on data analysis and interpretation, rather than prediction.

Considering the variety of fire data collection structures among countries and the difficulty in obtaining a robust model for the whole of Southern Europe, the study area was further divided in two regions, as described in the following section. OLS and GWR were applied separately in each region and the results compared. The resulting maps are expected to give an overview of the spatial patterns of fire occurrence and its main drivers throughout both regions, providing indications of the variations in the importance of the explanatory variables according to their spatial location.

\section{Material and methods}

\section{Study area}

This study was carried out for the countries of Southern Europe which are part of the European Forest Fire Information System
(EFFIS) network (Camia, Houston, \& San-Miguel-Ayanz, 2010; SanMiguel-Ayanz et al., 2012) with a minimum period of data available (at least 6 years). In spite of the harmonized standards already in place, the data collection structures differ among countries (SanMiguel-Ayanz et al., 2012); country data is gathered by the national fire or civil protection services and the information collected depends, to a certain extent, on the resources available in the countries, which vary widely within the European territory. Thus, although European countries have been gathering fire data for several decades, an inclusive transnational coordination on data collection and harmonization is an ongoing effort. For this reason, and after an exploratory analysis of the data, the available countries were grouped in 2 regions: Southwestern Europe (SW Europe) and Southeastern Europe (SE Europe) (Fig. 1). Greece is usually considered part of Southwestern Europe, however our exploratory analysis showed that Greece evidenced similar patterns to the countries of Southeastern Europe regarding fire density and frequency, hence it was included in this region instead; for the same reason, the Balkan countries with available data were included in Southeastern Europe, despite the geographical gap. For France, only the southern provinces, where fire frequency is similar to the remaining countries, were included in Southwestern Europe.

\section{Data collection and processing}

\section{Response variable}

The probability of fire occurrence results from the joint combination of an ignition source and the conditions for fire to spread (Jappiot et al., 2009; Oliveira et al., 2012); to represent ignitions, we obtained the number of fires recorded in the European Fire Database for each country (Camia, Durrant-Houston, \& San-MiguelAyanz, 2010; European Commission, 2012). This database compiles and harmonizes fire records from the participating countries since the 80's, the starting year varying according to country; for each individual fire event, specific information is added by the Forest Department and Civil Protection Services of the MemberStates, such as the date of the fire, the type of land cover affected, the burned area size, and the administrative region where it occurred, usually a descriptive location at NUTS3 level (corresponding in most countries to the level of provinces), whereas accurate geo-referencing of the fires is lacking for the most part. The number of fires recorded was aggregated at NUTS3 level for each country, for the period 1996-2010 when available, or the longest time-series of the country (at least 6 years). In view of the geolocation uncertainty associated with the fire records, fire density (number of fires/area $\mathrm{km}^{2}$ ) was used as a proxy of fire ignition. The calculation of fire density follows a similar procedure to the one used by Oliveira et al. (2012), thus only a brief explanation is presented here.

The fire events with accurate geo-referencing available in the database, for several countries, were used for an exploratory analysis of the proportion of fires occurring in different land cover types, as defined by the Corine Land Cover 2000 map (EEA-ETC/TE, Joint Research Centre [JRC], 2002). From this analysis, the land cover types associated with fire occurrence were aggregated in 2 main categories: wildland and non-wildland areas. Wildland areas include those land cover categories where fires are more likely to occur due to their typical vegetation cover, such as forests, shrublands and grasslands. Non-wildland areas, on the other hand, are those land cover types where a proportion of the fires can occur (or at least start), although their conditions are not typically related to the occurrence of wildland fire, such as agro-forestry areas. The land cover categories with a negligible contribution to fire occurrence, such as water bodies and continuous urban surfaces, as well as areas with elevation above $2000 \mathrm{~m}$, were excluded. It was found 


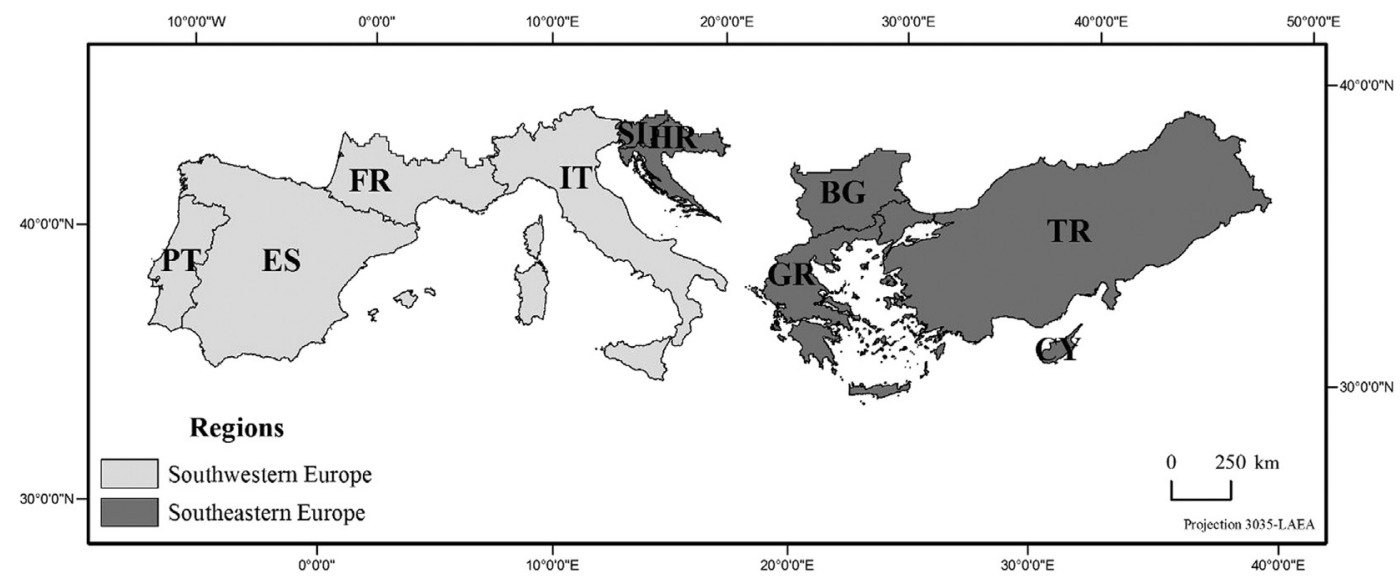

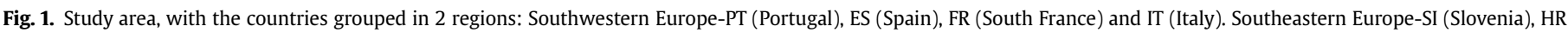
(Croatia), BG (Bulgaria), GR (Greece), TR (Turkey) and CY (Cyprus). The missing countries in Southern Europe did not have data available matching the criteria defined.

that, in general, $65 \%$ of the fires occur in Wildland areas and $35 \%$ in Non-Wildland areas; these proportions were then used to transform the statistical-based data into a gridded format, by distributing $65 \%$ of the average number of fires per NUTS3 in each country in wildland areas and $35 \%$ in non-wildland areas. A reference grid available for Europe at $10 \mathrm{~km}$, the selected spatial resolution (EEA, 2011), was superimposed and the number of points falling in each $10 \times 10 \mathrm{~km}$ grid cell was counted. Fire density corresponds to the mean annual number of fires per unit area $\left(\mathrm{km}^{2}\right)$, adjusted by the fire domain, i.e., the land area of that grid cell where fires could potentially occur, corresponding to the wildland and non-wildland areas previously identified and excluding those land cover types (such as water bodies, bare rocks and urban areas, among others) where wildland fires are not present (Oliveira et al., 2012).

Diagnostic tests were applied to the data and evidence of dissimilar variances was found; a log-transformation was applied to the dependent variable to approximate the values to a normal distribution. Each log value was then subtracted from the mean value of the region, yielding a response variable that corresponds to a deviance in relation to the average of the corresponding region, as follows:

$\mathrm{NF}=\mathrm{nf}-\operatorname{reg}(\mathrm{nf})$

With $\mathrm{nf}$ being the log of fire density of each cell and reg(nf) the average log (fire density) for the corresponding region, either Southwestern or Southeastern Europe.

\section{Explanatory variables}

The explanatory variables were selected according to two main criteria: their potential relation with fire occurrence and their availability for a minimum period of time suitable for long-term analysis. Considering that nearly $95 \%$ of fires in the southern Mediterranean region result from human activity (e.g. Leone, Lovreglio, Martín, Martínez, \& Vilar, 2009; Romero-Calcerrada, Barrio-Parra, Millington, \& Novillo, 2010; San-Miguel-Ayanz \& Camia, 2009), the human component is of major importance in the study area; both physical and anthropogenic variables were, thus, collected (Table 1) and transformed to a continuous scale at $10 \mathrm{~km}$ resolution; one value per grid cell was retrieved, using the reference grid.

Land cover. Land cover characterizes the distribution of land features related to nature, such as forests, water bodies or bare rocks, but also heterogeneous features that include the influence of human activities, for example urbanized and crop areas, as represented by Corine Land Cover (Heymann, Steenmans, Croissille, \& Bossard, 1994). This database is harmonized at European level and the classification incorporates as well human elements within its categories; bearing in mind the anthropogenic influence in fire activity in Southern Europe, and due to the lack of a harmonized fuel map at European level, land cover is here used as a surrogate for burnable vegetation types.

Previous studies have found an association between land cover and fire occurrence (e.g. Martínez, Vega-García, \& Chuvieco, 2009; Oliveira et al., 2012; Syphard et al., 2008; Vilar, Woolford, Martell, \& Martín, 2010). Certain land cover types are expected to have a positive correlation with fire occurrence, such as grassland, shrubland and forest; on the contrary, a high proportion of agricultural land is expected to have a negative association with fire occurrence (Carmo, Moreira, Casimiro, \& Vaz, 2011; Moreira, Vaz, Catry, \& Silva, 2009; Nunes et al., 2005; Oliveira, Moreira, Boca, San-Miguel-Ayanz, \& Pereira, 2013). From the aggregation of Corine classes, six different variables were obtained, each corresponding to a specific aggregation of land cover or vegetation categories where wildland fires may occur (Table 1).

Topography. The topographic features affect the spatial patterns of vegetation, its composition and flammability, besides influencing the local climatic conditions (Syphard et al., 2008; Whelan, 1995). Elevation, slope and aspect were retrieved from the DEM at European level (Jarvis, Reuter, Nelson, \& Guevara, 2008; Reuter, Nelson, \& Jarvis, 2007) and transformed to classes, as shown in Table 1. The proportion of the different topographic classes in each grid cell was then retrieved. In total, 12 variables were obtained. Higher proportions of lower elevation and lower slope classes are expected to have a positive influence in fire occurrence, due to the presence of vegetation and the better accessibility of these areas to anthropogenic ignition agents (Moreira et al., 2009; Oliveira et al., 2013).

Climate. Temperature and precipitation are recognized as being strong determinants of fire occurrence, because they directly affect vegetation growth rates and moisture (e.g. Bowman et al., 2009; Bravo, Kunst, Grau, \& Aráoz, 2010; Syphard et al., 2008; Vilar, Woolford, et al., 2010), thus influencing the likelihood of fire start and spread. Ensembles of daily gridded observational dataset from the E-OBS dataset (Haylock et al., 2008) were retrieved for the period 1995-2011. We selected this dataset due to its availability at European scale and because the time-series of the climatic variables matched the overall period of analysis of the fire data. Average 
Table 1

Explanatory variables used in the model and their sources.

\begin{tabular}{|c|c|c|c|c|c|}
\hline Variable type & Variable name & Code & $\begin{array}{l}\text { Resolution/ } \\
\text { scale }\end{array}$ & Source/reference & Description \\
\hline Land Cover & $\begin{array}{l}\text { Forest } \\
\text { Shrubland } \\
\text { Grassland } \\
\text { Other natural areas } \\
\text { Agricultural areas } \\
\text { Wildland Urban Interface }\end{array}$ & $\begin{array}{l}\text { forest } \\
\text { shrub } \\
\text { grass } \\
\text { other_nat } \\
\text { agric } \\
\text { wui }\end{array}$ & $\begin{array}{l}\text { Raster } \\
100 \mathrm{~m}\end{array}$ & $\begin{array}{l}\text { CLC 2000/2006 } \\
\text { EEA-ETC/TE, JRC, } 2002\end{array}$ & $\begin{array}{l}\text { Proportion of each land cover type in each grid cell. } \\
\text { Forest }=23-25 ; \text { Shrubland }=27-29 ; \text { Grassland }=18 \text {, } \\
26 ; \text { Other natural areas }=21-22,32-33 ; \text { Agricultural } \\
\text { areas }=12,15-17,19-20) ; \text { WUI }=2\end{array}$ \\
\hline Topographic & $\begin{array}{l}\text { Elevation } 0-500 \mathrm{~m} \\
\text { Elevation } 500-1000 \mathrm{~m} \\
\text { Elevation } 1000-1500 \mathrm{~m} \\
\text { Elevation above } 1500 \mathrm{~m} \\
\text { Slope } 0-10 \% \\
\text { Slope } 10-20 \% \\
\text { Slope } 20-30 \% \\
\text { Slope above } 30 \% \\
\text { Aspect N (315-45 deg) } \\
\text { Aspect E (45-135 deg) } \\
\text { Aspect S (135-225 deg) } \\
\text { Aspect W (225-315 deg) }\end{array}$ & $\begin{array}{l}\text { elev0_500 } \\
\text { elev500_1000 } \\
\text { elev1000_1500 } \\
\text { elev_ab1500 } \\
\text { slope0_10 } \\
\text { slope10_20 } \\
\text { slope20_30 } \\
\text { slope_ab30 } \\
\text { aspect_N } \\
\text { aspect_E } \\
\text { aspect_S } \\
\text { aspect_W }\end{array}$ & $\begin{array}{l}\text { Raster } \\
100 \mathrm{~m}\end{array}$ & $\begin{array}{l}\text { DEM Europe } \\
\text { Jarvis et al. 2008; } \\
\text { Reuter et al. } 2007\end{array}$ & $\begin{array}{l}\text { Proportion of each elevation class per grid cell } \\
\text { Proportion of each slope class per grid cell } \\
\text { Proportion of each aspect class per grid cell }\end{array}$ \\
\hline Climatic & $\begin{array}{l}\text { Average maximum } \\
\text { temperature June-October } \\
\text { Average maximum } \\
\text { temperature other months } \\
\text { Cumulative precipitation } \\
\text { June-October } \\
\text { Cumulative precipitation } \\
\text { other months }\end{array}$ & $\begin{array}{l}\text { tmax_fs } \\
\text { tmax_nfs } \\
\text { prec_fs } \\
\text { prec_nfs }\end{array}$ & $\begin{array}{l}0.25 \mathrm{deg} \\
(28 \mathrm{~km})\end{array}$ & $\begin{array}{l}\text { E-OBS } \\
\text { 1995-2011 } \\
\text { Haylock et al. } 2008\end{array}$ & $\begin{array}{l}\text { Downscaled based on inverse distance weighted interpolation, } \\
\text { assuming that the values of the closest stations are more } \\
\text { alike than those that are farther apart. }\end{array}$ \\
\hline Infrastructure & $\begin{array}{l}\text { Density highways } \\
\text { Density main roads } \\
\text { Density local roads } \\
\text { Density electric lines }\end{array}$ & $\begin{array}{l}\text { highway } \\
\text { main_road } \\
\text { local_road } \\
\text { electric }\end{array}$ & $\begin{array}{l}1 / 100.000 \\
\text { Vector }\end{array}$ & $\begin{array}{l}\text { TeleAtlas, } 2007 \\
\text { Platts, } 2006 \\
\text { (IET support, Petten) }\end{array}$ & $\begin{array}{l}\text { Length } / \mathrm{km}^{2} \text { - Level } 00 \\
\text { Length } / \mathrm{km}^{2} \text { - Levels } 01-03 \\
\text { Length } / \mathrm{km}^{2} \text { - Levels } 04-06 \\
\text { Length } / \mathrm{km} \text { - transmission lines }\end{array}$ \\
\hline Demographic & $\begin{array}{l}\text { Average population density } \\
\text { Intermediate urban areas }\end{array}$ & popdens & $1: 3$ million & $\begin{array}{l}\text { Gallego, } 2010 \\
\text { Gallego, Batista, Rocha, } \\
\text { \& Mubareka, } 2011 \\
\text { Eurostat (TR) } \\
\text { Eurostat, GISCO } 2001\end{array}$ & Proportion of intermediate urban area in each grid cell \\
\hline Livestock & $\begin{array}{l}\text { Density of cattle } \\
\text { Density of goats } \\
\text { Density of sheep }\end{array}$ & $\begin{array}{l}\text { cattle } \\
\text { goat } \\
\text { sheep }\end{array}$ & NUTS3 & $\begin{array}{l}\text { Eurostat regional } \\
\text { statistics (agriculture), } \\
2010\end{array}$ & $\begin{array}{l}\text { Average number of animals per } \mathrm{km}^{2} \text { of the total agricultural } \\
\text { land. Adjusted rate based on proportion of NUTS3 in each cell }\end{array}$ \\
\hline
\end{tabular}

maximum temperature and precipitation were the variables retrieved, at a resolution of $0.25^{\circ}$ (approx. $28 \mathrm{~km}$ ). Temperature and precipitation values were divided into two seasons: June-October and the remaining months. The June-October season (here called summer) represents the hottest and driest months in Southern Europe, when high values of precipitation are unusual but will have a negative influence in fire occurrence by increasing fuel moisture content, whereas temperatures are usually high and will reduce the moisture content of vegetation; on the other hand, precipitation in the other months (non-summer) is likely to favor vegetation growth and increase the availability of fine fuels, thus having a positive association with fire occurrence (Flannigan et al., 2013; Meyn, White, Buhk, \& Jentsch, 2007; Oliveira et al., 2012; Pausas, 2004; Pereira, Trigo, Dacamara, Pereira, \& Leite, 2005).

Infrastructures. Roads have been pointed out as influencing factors of fire occurrence (Catry, Rego, Bação, \& Moreira, 2009; Martínez et al., 2009; Oliveira et al., 2012; Romero-Calcerrada, Novillo, Millington, \& Gomez-Jimenez, 2008; Vilar, Woolford, et al., 2010), as it is associated with the accessibility of the area to human ignition agents. The road network data from Tele Atlas (Tele Atlas, 2007) was used to calculate road density, defined as road length per unit area. Density of power lines was also included, assuming the possibility of electric discharges causing ignitions (European Commission, 2012; Vasilakos, Kalabokidis, Hatzopoulos, \& Matsinos, 2008).

Demographic. The effect of demographic factors on fire occurrence can be two-fold: on the one hand, high population densities increase the possibility of human-caused ignitions; on the other hand, they also contribute to reduce fuel availability and change vegetation patterns, resulting in decreased fire occurrence (Archibald, Nickless, Govender, Scholes, \& Lehsten, 2010; Bistinas et al., 2013; Sá et al., 2011). Population density per cell was, thus, included as a variable in the model.

The proportion of intermediate urban areas (EUROSTAT, 2001) in each cell was also retrieved, because it indicates areas of urban sprawl, adjacent to densely urbanized ones, with relatively high number of ignition agents (at least 50,000 people), good accessibility and an intermediate level of human activity.

Livestock. Livestock was disaggregated by type of animal, considering their diverse characteristics and based on results from previous studies. On the one hand, the abundance of goat and sheep was found to correlate with the absence of fire ignitions (RomeroCalcerrada et al., 2008; Sebastián-López et al., 2008), because these 
species feed on grass and bushes and reduce the amount of vegetation available, particularly fine fuels. On the contrary, other studies have identified livestock density as being positively correlated to fire occurrence (Koutsias et al., 2010; Martínez et al., 2009; Oliveira et al., 2012), probably due to burning activities for pasture renovation. Data on cattle, sheep and goat, associated with outdoor farming activities and pasture management, were obtained as individual variables.

\section{Methods}

Collinearity among explanatory variables was assessed, in a first stage, by calculating the Pearson product-moment correlation. Correlation coefficients above 0.7 were used as a criterion to remove variables. Explanatory variables with a negligible relationship with the response variable were also removed. In a second stage, the variance inflation factor (VIF), which quantifies how much an estimated regression coefficient increases due to multicollinearity, was calculated for the remaining variables, using $\mathrm{R}$ Statistical Software (R Development Core Team, 2011). Only the explanatory variables with VIF values close to 1 were included. This procedure was applied to each region separately.

Geographically Weighted Regression. This method has been explained in detail by several authors (Fotheringham et al., 2002; Koutsias et al., 2010; Sá et al., 2011; Wang, Ni, \& Tenhunen, 2005), thus only a brief description of its application to our dataset is presented here.

Relationships between fire density and the explanatory variables were derived for each region separately. GWR (version 3.0,Fotheringham et al., 2002) was applied to each region and a comparison with the performance of the Ordinary Least Squares (OLS) model was done. While OLS assumes stationarity and calculates the coefficients for the global model, GWR allows verifying if the relationships between the response variable and the explanatory variables vary in space, by calculating regression coefficients at each individual location (Fotheringham et al., 2002; Koutsias et al., 2010; Sá et al., 2011). These studies have shown the better performance of the GWR model in relation to OLS with fire occurrence and incidence data, thus the results presented are mainly to provide indication of the general influence of the explanatory variables over the region. The bandwidth, which is the distance radius around each observation point that comprises the observations to be used in the weighting matrix (Fotheringham et al., 2002), in this case a fixed distance since the grid cell values are equally spaced at $10 \mathrm{~km}$, was obtained by minimizing the corrected Akaike information criterion (AICc) in each region. The local statistical significance of the coefficient estimates was assessed with a $t$-test and the distribution of the significant variables and the values of $R^{2}$, which give indication of the model fit in each cell, were mapped using GIS tools. The level of importance of the variables, in explaining the distribution of the dependent variable, was obtained from the highest absolute $T$-value found in each cell.

To reduce the degree of dependency rate that results from the use of the same dataset to calibrate the model and control the family-wise error rate from the multiple hypotheses testing, the significance levels of $T$-values were adjusted using the formula provided by Byrne, Charlton, and Fotheringham (2009).

Spatial autocorrelation. Spatial autocorrelation was analyzed to determine whether the GWR model accounts for the spatial structure of the dependent variable and if it represents an improvement in relation to OLS, by showing a reduction in the spatial autocorrelation of the residuals (Koutsias et al., 2010; Sá et al., 2011).
The presence of spatial autocorrelation in the model residuals was tested by building semivariograms, which plot the semivariance as a function of distance, and by analyzing clumping of model residuals.

\section{Results}

Fire density

Mean annual fire density varies largely among countries and regions in Southern Europe, as shown in Fig. 2, which represents the original values of fire density (non-transformed). The highest values are concentrated in northwest of Iberia, while the eastern part of Southeast region generally evidences lower values of fire density.

\section{Explanatory variables}

High correlation values were found between the explanatory variables of different categories and within the same category, particularly land cover, topography and climate. Some of the explanatory variables also showed low correlation with the dependent variable. From the initial set of 32 variables, 12 were selected for Southwestern Europe and 16 for Southeastern Europe (Fig. 3), based on the correlation with the response variable and the absence of collinearity with other predictors.

The explanatory variables selected were slightly different between the two regions; in Southwestern Europe, the wildlandurban interface (wui) was highly correlated to population density and temperature with slope, while in Southeastern Europe this was not observed, thus the latter model included a higher number of explanatory variables.

\section{Global model of fire occurrence}

The global model for Southwestern Europe explained 37\% of the variance, while for Southeastern Europe this value was only 13\% (Table 2). It is evident that the global models do not capture entirely the influence of the variables, particularly for Southeastern Europe where the adjusted $R^{2}$ value is very low.

The parameters estimates and $T$ values provide, nevertheless, an overall indication of the most important variables and the direction of the association. For both regions, precipitation of the nonsummer season showed the higher $T$ values and a positive association, followed by topographic and livestock variables (Tables 3 and 4). In Southwestern Europe, slope $0-10 \%$ is the second most important variable, with a positive relationship, while in Southeastern Europe elevation $0-500 \mathrm{~m}$ shows the second highest $T$ value, also with a positive direction. Cattle and goat density come next for Southwestern Europe, with a positive association, whereas for Southeastern Europe, goat density presents a negative relationship with the dependent variable.

\section{GWR and local variations of variable influence}

The results obtained with GWR showed a significant improvement in relation to OLS in both regions, although at different levels (Tables 5 and 6). For Southwestern Europe, the GWR model performs better than for Southeastern Europe, with the $R^{2}$ values reaching $82 \%$ and $47 \%$, respectively.

The $R^{2}$ values show a dissimilar distribution within each region (Fig. 4). In SW Europe, the higher values are concentrated in the Western Iberian Peninsula and northwest Italy. The eastern part of Spain and northeast Italy show lower values, below 0.2 . 


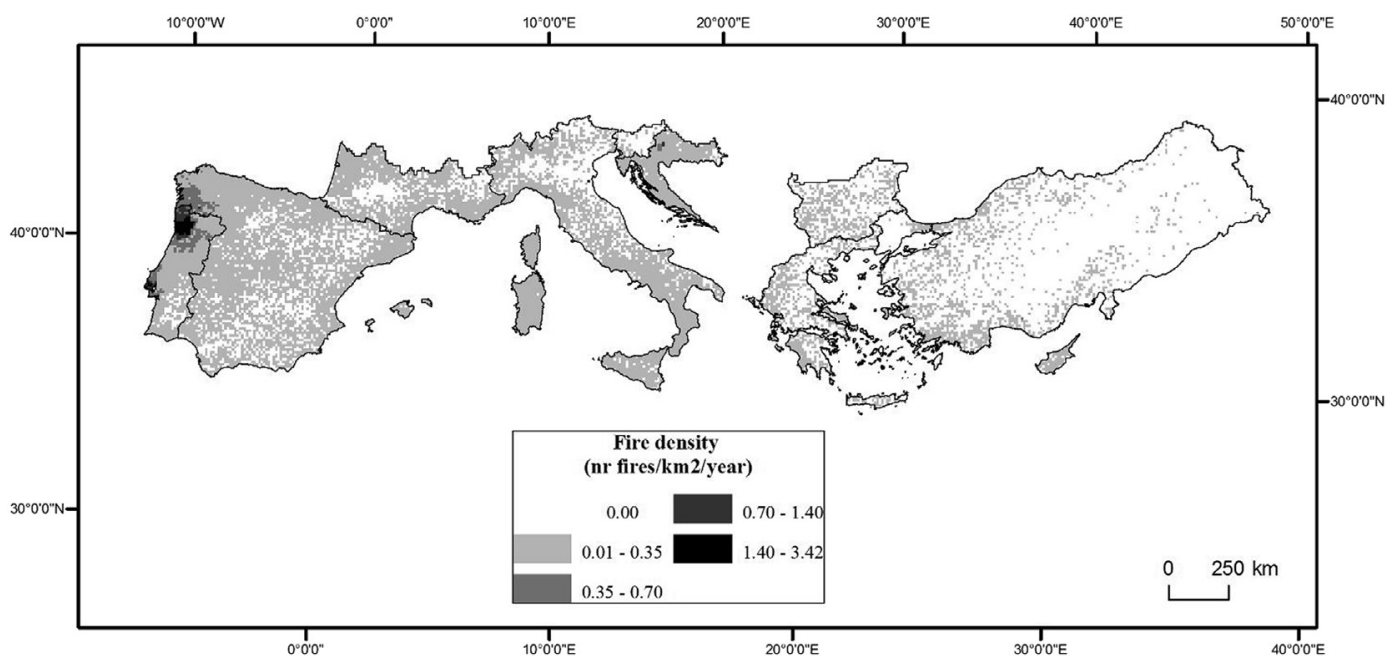

Fig. 2. Mean annual fire density in the study area (original values, before log transformation).

(a)

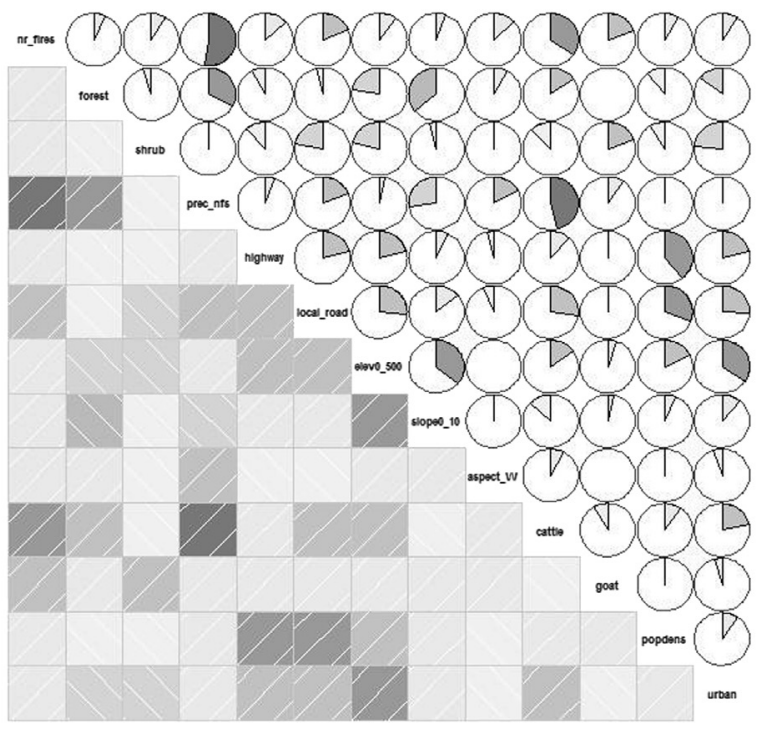

(b) Correlation variables Southeastern Europe

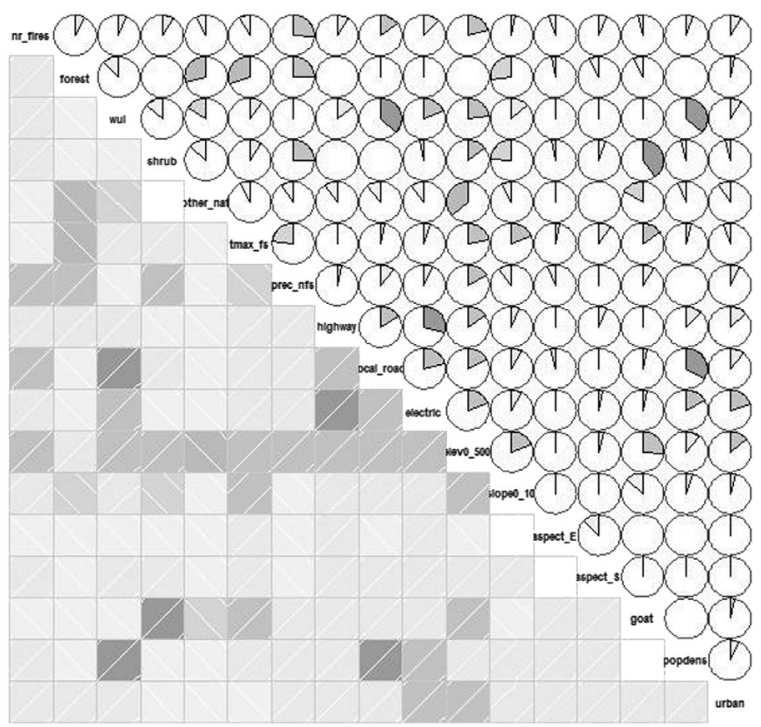

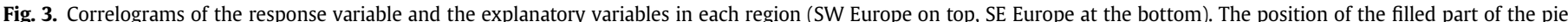

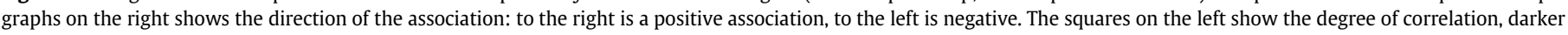
shade means higher value (Wright, 2011).

In SE Europe, the spatial distribution of $R^{2}$ values show a general decreasing trend from West to East, with the Balkan countries showing the highest values, although below 0.5 , and eastern Turkey the lowest $R^{2}$. Cyprus shows higher values, similar to those found for the Balkan countries.

Table 2

Results of the OLS model for the two regions.

\begin{tabular}{lll}
\hline Parameters OLS & SW Europe & SE Europe \\
\hline Nr observations & 11,324 & 12,133 \\
Residual sum of squares & 17.663 & 2.270 \\
Effective number of parameters & 13 & 17 \\
Sigma & 0.040 & 0.040 \\
Akaike information Criterion & $-41,025$ & $-69,682$ \\
Coefficient of determination & 0.371 & 0.130 \\
Adjusted $r$-square & 0.370 & 0.129 \\
\hline
\end{tabular}

Note: Sigma refers to the standard error of the estimate.
Table 3

Parameter estimates and VIF values of the OLS model for Southwestern Europe.

\begin{tabular}{lclrl}
\hline Variables & Estimate & Std error & \multicolumn{1}{l}{$T$} & VIF \\
\hline Intercept & -0.152 & 0.004 & -42.137 & \\
forest & -0.10 & 0.002 & -5.652 & 1.295 \\
shrub & 0.030 & 0.002 & 13.113 & 1.176 \\
prec_nfs & 0.000 & 0.000 & 51.729 & 1.544 \\
highway & 0.065 & 0.008 & 7.897 & 1.250 \\
local_road & 0.004 & 0.001 & 3.433 & 1.339 \\
elev0_500m & -0.005 & 0.001 & -4.998 & 1.422 \\
slope0_10perc & 0.072 & 0.003 & 21.232 & 1.376 \\
aspect_W & 0.028 & 0.005 & 5.922 & 1.053 \\
cattle & 0.000 & 0.000 & 18.391 & 1.428 \\
goat & 0.000 & 0.000 & 18.361 & 1.083 \\
popdens & 0.000 & 0.000 & 2.729 & 1.284 \\
urban & 0.007 & 0.001 & 4.750 & 1.268 \\
\hline
\end{tabular}


Table 4

Parameter estimates and VIF values of the OLS model for Southeastern Europe.

\begin{tabular}{lrlrl}
\hline Variables & Estimate & Std error & \multicolumn{1}{l}{$T$} & VIF \\
\hline Intercept & -0.006 & 0.002 & -3.089 & \\
forest & 0.001 & 0.001 & 1.402 & 1.453 \\
wui & -0.003 & 0.002 & -1.411 & 1.394 \\
shrub & 0.006 & 0.001 & 7.139 & 1.399 \\
other_nat & 0.001 & 0.001 & 1.492 & 1.374 \\
tmax_fs & 0.000 & 0.000 & -7.574 & 1.287 \\
prec_nfs & 0.000 & 0.000 & 20.059 & 1.261 \\
highway & 0.016 & 0.006 & 2.753 & 1.132 \\
local_road & 0.007 & 0.001 & 9.501 & 1.281 \\
electric & 0.007 & 0.001 & 6.019 & 1.195 \\
elev0_500m & 0.006 & 0.000 & 17.232 & 1.444 \\
slope0_10perc & 0.003 & 0.001 & 2.446 & 1.282 \\
aspect_E & -0.003 & 0.001 & -2.580 & 1.027 \\
aspect_S & 0.007 & 0.001 & 6.253 & 1.035 \\
goat & 0.000 & 0.000 & -11.999 & 1.305 \\
popdens & 0.000 & 0.000 & -0.412 & 1.230 \\
urban & 0.004 & 0.001 & 2.764 & 1.077 \\
\hline
\end{tabular}

To assess the levels of significance, $p$-values were corrected according to the formula used by Byrne et al. (2009) and Sá et al. (2011), with $p=0.000080$ and $p=0.000247$ for SW and SE Europe respectively, for $\alpha=0.05$. The number of significant variables, assessed with the corrected $p$-values, generally decreases from West to East in both regions, identical to the pattern verified for the levels of $R^{2}$, with the western part showing a higher number of significant explanatory variables in relation to the remaining area, although some clusters can be found throughout the regions. The maximum number of significant variables in SW Europe is higher than for SE Europe, even though the latter included more explanatory variables in the model. In 67\% of the area in SW Europe, no significant variable was found, $13 \%$ has 1 significant variable and $12 \%$ from 2 to 5 variables. In SE Europe, $50 \%$ of the region has no significant variable, $30 \%$ has 1 significant variable and $12 \%$ from 2 to 5 significant variables (Fig. 5)

Regarding the most important variables, non-summer precipitation, goat density and proportion of forest and shrubland appear in both regions as the most significant parameters in specific areas (Fig. 6). Goat density and precipitation together cover over $55 \%$ of the area in SW Europe where there is at least 1 significant variable, whereas in SE Europe this proportion increases to 66\%. The influence of precipitation is mostly concentrated in Northern Portugal and East of Spain in SW Europe, and in SE Europe all over Greece and in the SW of Turkey. Goat density is more significant in NW Spain, Sardinia, in Italy and in central-south of Turkey.

In the northwest of the Iberian Peninsula (SW Europe), where higher values of $R^{2}$ were found, the effects of precipitation and goat density are particularly evident, both with a positive association with fire occurrence. Cattle and population density also appear locally as the most significant parameter in this region, covering, respectively, 15 and $12 \%$ of the area where there is at least 1 significant variable. In SE Europe, local roads cover $17 \%$ and highway $7 \%$ of the region. The proportion of shrubland covers around $5 \%$ and

Table 5

GWR parameters obtained for the two regions.

\begin{tabular}{lll}
\hline Parameters GWR & SW Europe & SE Europe \\
\hline Nr observations & 11,324 & 12,133 \\
Bandwidth (in meters) & 58,533 & 148,086 \\
Residual sum of squares & 4.731 & 1.373 \\
Effective number of parameters & 628 & 202 \\
Sigma & 0.040 & 0.040 \\
Akaike information Criterion & $-54,639$ & $-75,404$ \\
Adjusted $r$-square & $\mathbf{0 . 8 2 1}$ & $\mathbf{0 . 4 6 5}$ \\
\hline
\end{tabular}

Table 6

ANOVA results with the comparison of OLS and GWR models for the two regions.

\begin{tabular}{lcc}
\hline ANOVA & SW Europe & SE Europe \\
\hline GWR improvement Mean Square & 0.021 & 0.005 \\
GWR residuals Mean Square & 0.000 & 0.000 \\
F-value (ANOVA) & $\mathbf{4 7 . 5 3 7}$ & $\mathbf{4 2 . 1 1 6}$ \\
\hline
\end{tabular}

$7 \%$ of the area with significant variables in SW and SE Europe, respectively.

The direction of the association between fire density and the significant factors shows an interesting spatial variation; in SW Europe, goat density has a positive correlation with fire density, whereas in Turkey (SE Europe), some areas show goat density having a negative association with the dependent variable. Forest shows a negative relationship with fire density in both regions, whereas shrubland has a positive association.

\section{Spatial autocorrelation}

The spatial distribution of residuals for the OLS models reveals clustering, whereas for GWR the spatial pattern evidences a less structured distribution (Figs. 7 and 8). The semivariograms (Fig. 9) indicate spatial autocorrelation for the dependent variable up to $700 \mathrm{~km} \mathrm{lag}$, with the semivariance decreasing afterwards up to $1500 \mathrm{~km}$, beyond which it increases again. The GWR model showed lower values of semivariance, as well as a flat semivariance line throughout most of the distance, up to $1500 \mathrm{~km}$ lag. This holds true particularly for SW Europe, while for SE Europe none of the models shows an effective decrease in the spatial autocorrelation of the residuals, although semivariance values for GWR are lower than for OLS.

\section{Discussion}

\section{GWR and OLS performance}

Fires occur throughout Southern Europe, although with strong spatial variability and under the influence of different factors. The application of a method that captures local variations in the influence of the explanatory variables revealed major improvements in relation to global models, when applied at broad scale. Our results suggest that GWR performs better than OLS in modeling fire occurrence overall, in spite of the different levels of model fit dependent on the area. These results agree with previous studies, which showed the potential of GWR for modeling fire occurrence at a large scale (Koutsias et al., 2010; Sá et al., 2011). GWR also seemed to deal better with spatial autocorrelation in the residuals, although the method does not address this issue directly (Koutsias et al., 2010). This means that the spatial patterns of the dependent variable could be explained by the spatial patterns observed in the explanatory variables included in the model (Dormann et al., 2007; Legendre \& Legendre, 2012). The geographical discontinuities in Southeastern Europe, a region made of many islands, a convoluted coastline and spatial gaps, may partially explain the less powerful effect of GWR in addressing spatial autocorrelation. Nevertheless, GWR showed lower autocorrelation values in the residuals and a more random spatial distribution in both regions, in comparison to OLS.

\section{Variable importance at global level}

At a global level, OLS revealed the importance of the climatic variables in both regions, particularly non-summer precipitation, to 

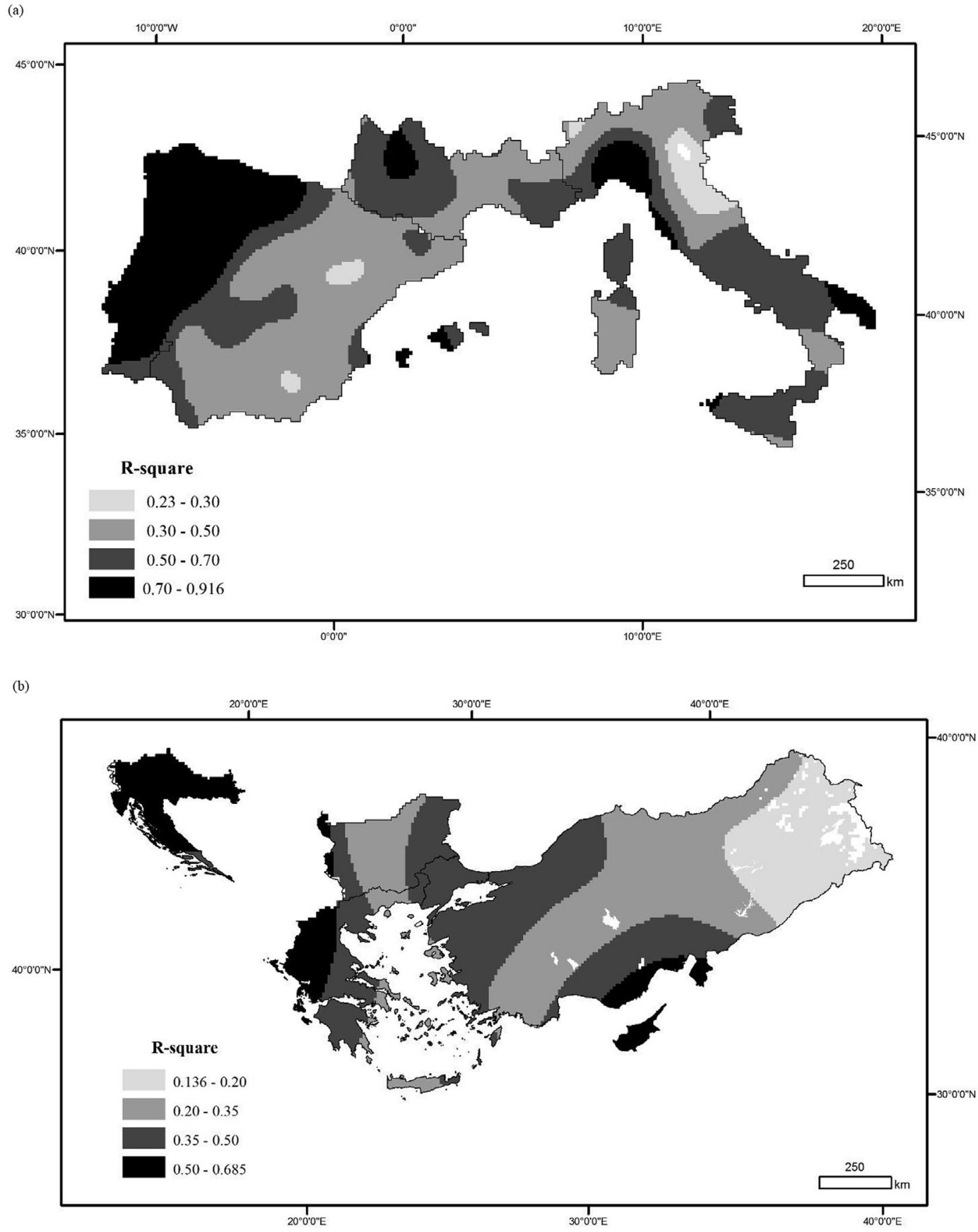

Fig. 4. Distribution of GWR local $R^{2}$ values in Southwestern Europe (a) and Southeastern Europe (b).

explain fire occurrence. The strong association between fire and precipitation has been previously indicated (Bravo et al., 2010; Carvalho et al., 2010; Cary et al., 2006; Drever, Drever, Messier, Bergeron, \& Flannigan, 2008; Oliveira et al., 2012; San-MiguelAyanz, Moreno, \& Camia, 2013). Our results suggest that precipitation in the winter months may contribute to the growth of vegetation and to an increase in fuel loads that will be available to burn in the dry season, as mentioned as well by Pausas (2004) and Moreno et al. (2011). The importance of the lower elevation and slope values is most likely related to the accessibility of the areas to ignition agents, indicating the contribution of anthropogenic variables for fire occurrence; other authors have also suggested a strong association between fire occurrence and human access to the landscape (Conedera et al., 2011; Oliveira et al., 2013; RomeroCalcerrada et al., 2010).

The human influence on fires in Southern Europe is further confirmed by the significance of livestock variables; on one hand, the positive association of cattle and goat density verified in Southwestern Europe suggests the influence of agricultural activities in fire occurrence, possibly related to burning for pasture management, a relationship found as well in previous studies (Carmo et al., 2011; Ganteaume et al., 2013; Koutsias et al., 2010; Martínez et al., 2009; Nunes, 2012). In Southeastern Europe, on the other hand, the association with goat density is negative in particular areas in Turkey, possibly related to overgrazing by goats in this region, where grasslands are the most frequent land cover 

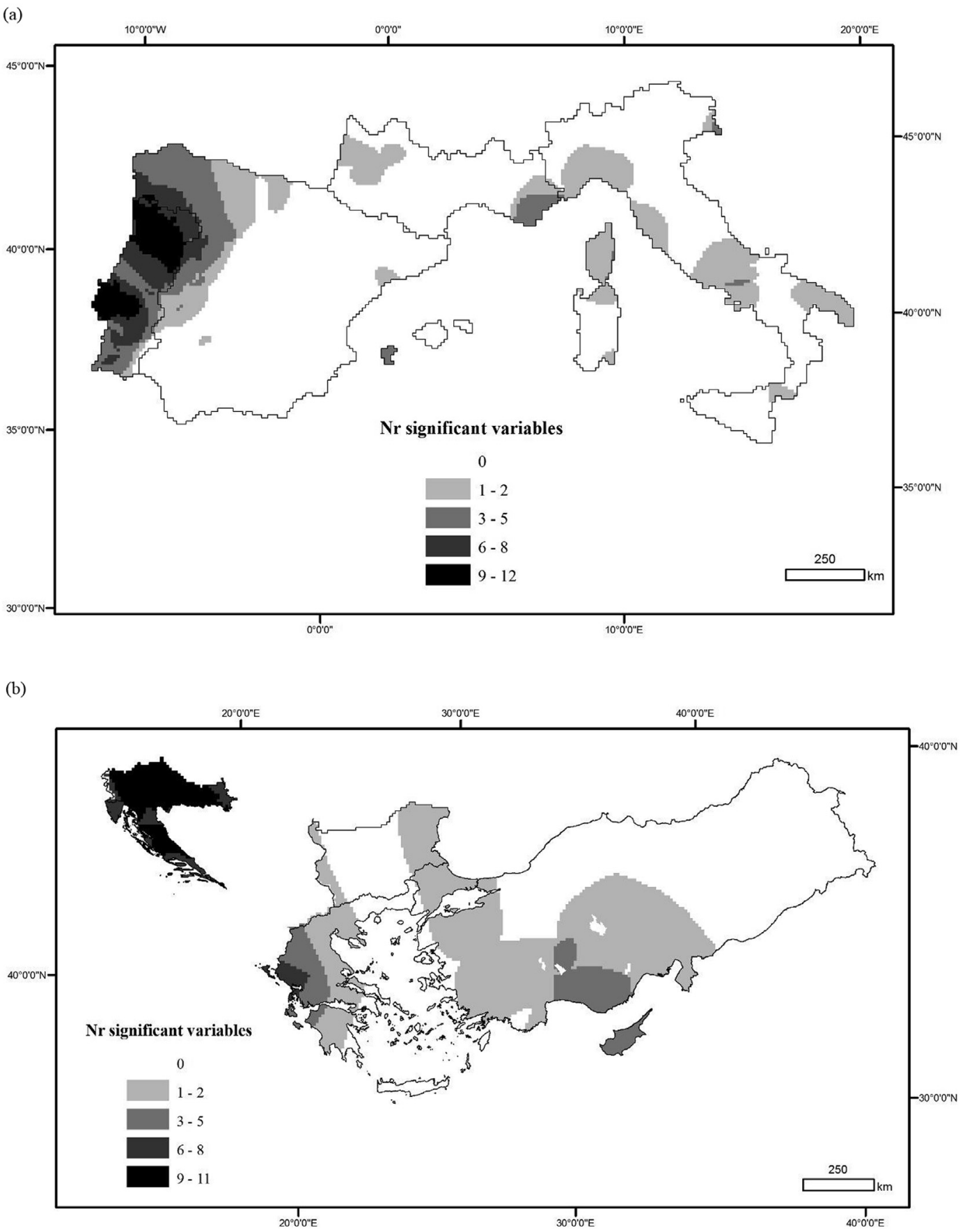

Fig. 5. Number of significant variables per cell in Southwestern Europe (a) and Southeastern Europe (b).

type (EEA, 2012; Roekaerts, 2002); the abundance of goats reduces the amount of fine fuels available to burn, similarly to what has been reported for other areas by Romero-Calcerrada et al. (2008) and Sebastián-López et al. (2008).

Local and regional variations in variable importance

The GWR model uncovered strong spatial variability in the explanatory power of the variables throughout the study area. The significance of the variables common to SW and SE Europe, namely non-summer precipitation, goat density and proportion of shrubland, varies within each region. These results confirm the influence of climatic, vegetation-related and human activities (agriculture) on fire occurrence in different regions (Bowman et al., 2009), although at different extents. Besides the strong relationship of fire with precipitation and livestock activities, previously explained, shrubland has also been associated with fire and, in some studies, was considered more fire-prone than forests (Carmo et al., 2011; Mermoz, Kitzberger, \& Veblen, 2005; Moreira et al., 2009; Nunes et al., 2005; Oliveira et al., 2013), thus the positive association with fire occurrence is somewhat expected.

In SW Europe, also population density was found to be significant in specific areas, evidencing the relevance of human-caused ignitions in this region, as pointed out as well by other authors (Leone et al., 2009; Nunes, 2012; Romero-Calcerrada et al., 2010; San-Miguel-Ayanz et al., 2013; Vilar, Nieto, et al., 2010). 

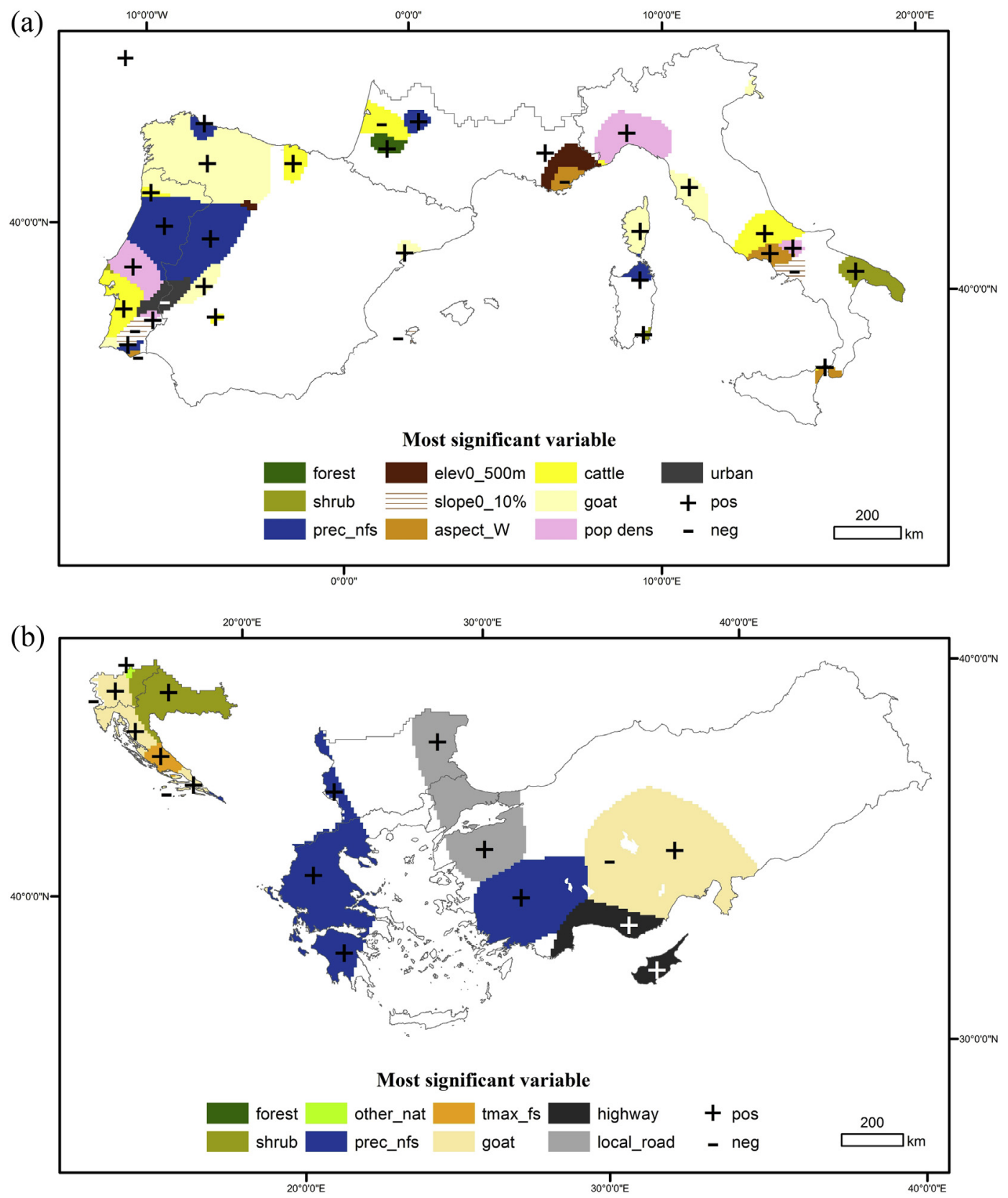

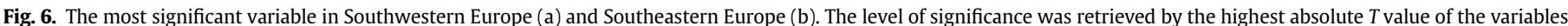
in each cell. The symbols show the positive $(+)$ or negative $(-)$ association with fire density.

In SE Europe, the significance of transportation infrastructure, namely local roads in the north of Turkey and highways in parts of southern Turkey and Cyprus, is a surprising result and difficult to explain. Highway density is rather low in the country and the values of fire density are also generally low in the area. As such, even a slight increase in roads density, which may represent an increase in accessibility, may correlate statistically to higher values of fire density.

\section{Implications of country-specific conditions}

Although long-term assessment of the spatial determinants of fire density implies the use of averaged values, it is clear that the results obtained partly reflect the influence of extreme fire seasons, occurred particularly in SW Europe during the study period.
Portugal is one of the most affected countries in this region (Carvalho et al., 2011; European Commission, 2012; San-MiguelAyanz et al., 2013) and the summer of 2003 and 2005 were particularly difficult with extensive damages, caused by several large fire events due to the extreme climatic conditions (Pereira et al., 2005; Trigo et al., 2006). Furthermore, since the dependent variable was derived from statistical databases compiled originally at national levels, data compatibility issues may arise, which hinder the application of a suitable model at a broad scale. The results of the model, whose performance favors particular areas, can partially be a result of the data idiosyncrasies, as for example, with Portugal having more fire events and more data available than the other countries. The availability of reliable and harmonized data at global level is, indeed, one of the limitations of broad-scale studies. Moreover, the GWR model showed, in both regions, large areas 

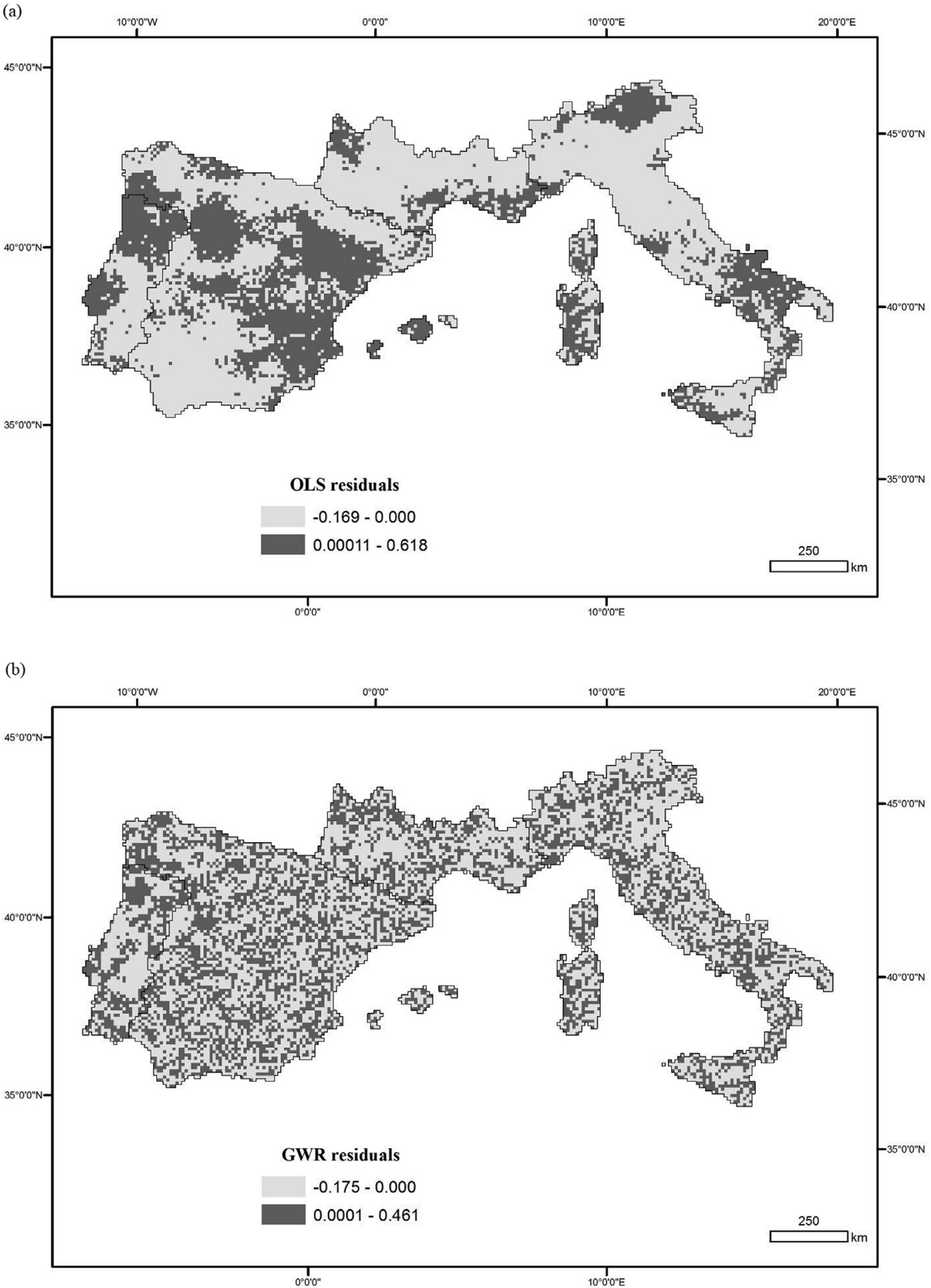

Fig. 7. Spatial patterns of residuals for the OLS model (a) and GWR (b) for Southwestern Europe.

where none of the explanatory variables was significant. These areas generally correspond to grid cells where fire density was low or null; in fact, the number of significant variables increases with increased values of fire density, which indicates a better fit of the model when fire data is more available. This also implies that, to explain fire occurrence patterns in the areas with low fire density, where the variables included didn't show a significant effect, other factors should be investigated and considered in the future, bearing in mind that such variables, if too local, may not be available for a broad study area as the one used in this research.

\section{Conclusion}

This study intended to provide a better understanding of the spatial variability of long-term fire occurrence in Southern Europe, as well as the relative importance of the underlying factors. It had 

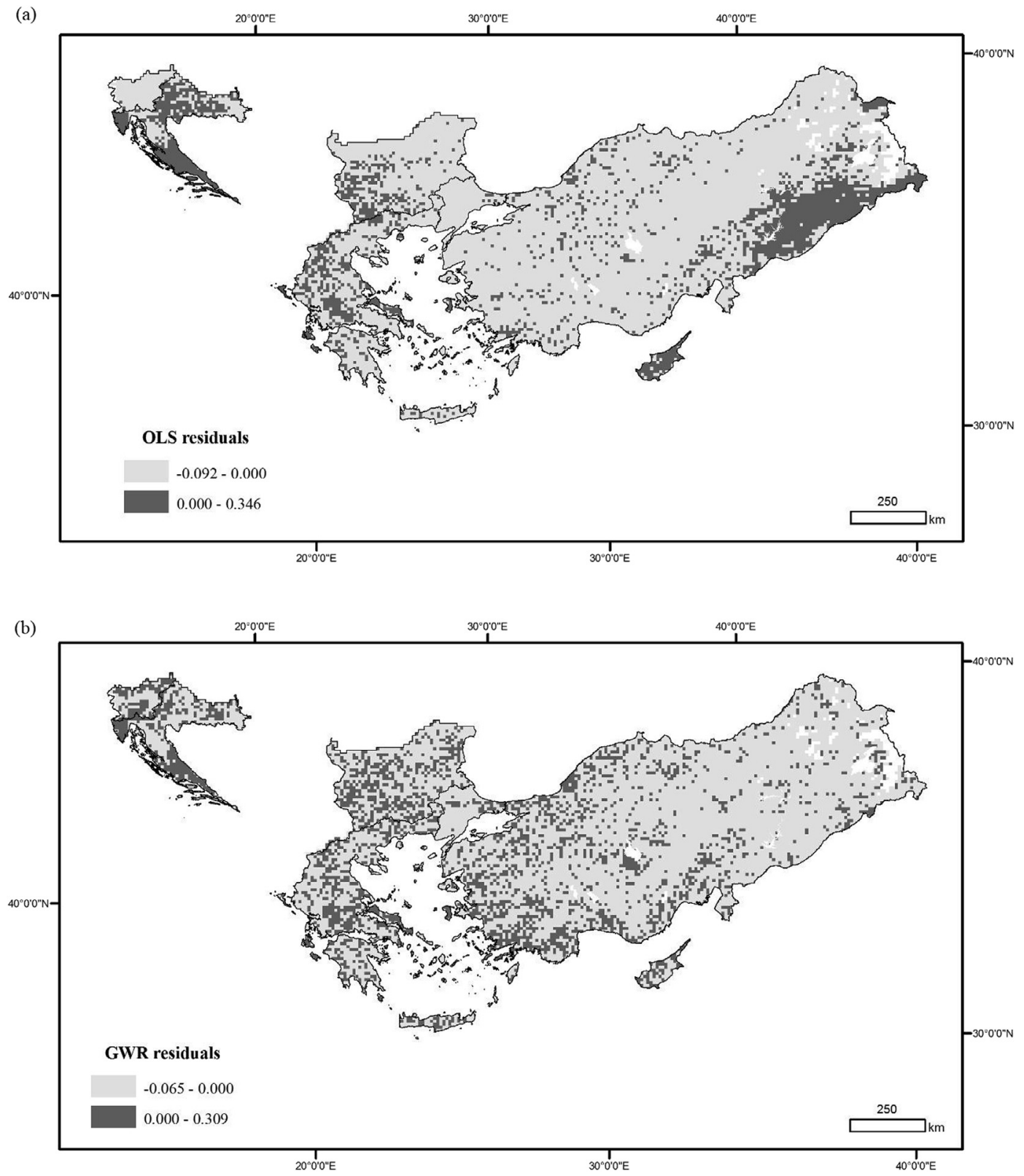

Fig. 8. Spatial patterns of residuals for the OLS model (a) and GWR (b) for Southeastern Europe.

also the purpose to contribute to the discussion around the feasibility and limitations of fire occurrence assessment at large scales, required by the transboundary nature of fire activity and its impacts. The use of Geographically Weighted Regression proved to be beneficial, as this method captured the spatial attributes of the phenomenon being studied and provided higher accuracy than the global model, while revealing the localized patterns derived from the influence of particular variables.

In spite of the difficulties in obtaining reliable data in a sufficient time-scale suitable for long-term analysis, this study is a contribution to the ongoing research on the drivers of fire occurrence in Southern Europe, showing the importance of the climatic variables, agricultural activities and land cover in several regions and countries.

These findings clearly indicate that precipitation patterns and land cover are paramount to explain the distribution of fire density in different parts of Southern Europe. In this context, and since climate cannot be controlled by man, the application of prevention measures should focus on the management of vegetation, bearing in mind the influence of autumn and winter rainfall in fuel loads that will be available to burn in summer. Prescribed fires are a potential tool to reduce fire hazard by decreasing fuel loads before the driest season (Fernandes et al., 2013) and should receive further attention by fire managers.

Our results also show that, in these regions, the occurrence of fires is highly influenced by human activities. The importance of population density in Southwestern Europe, particularly in Central Portugal and NW Italy, indicate the need of increasing population awareness regarding their role on fire ignitions, as well as the implications of their actions for the protection of human and natural assets from fire. Public sensitization campaigns through the media and educational activities in schools, applied in a consistent way, are required to change human behavior. These campaigns, to be effective, must be adjusted to the particular cultural conditions and integrated in the educational system of each country and region. 
(a)
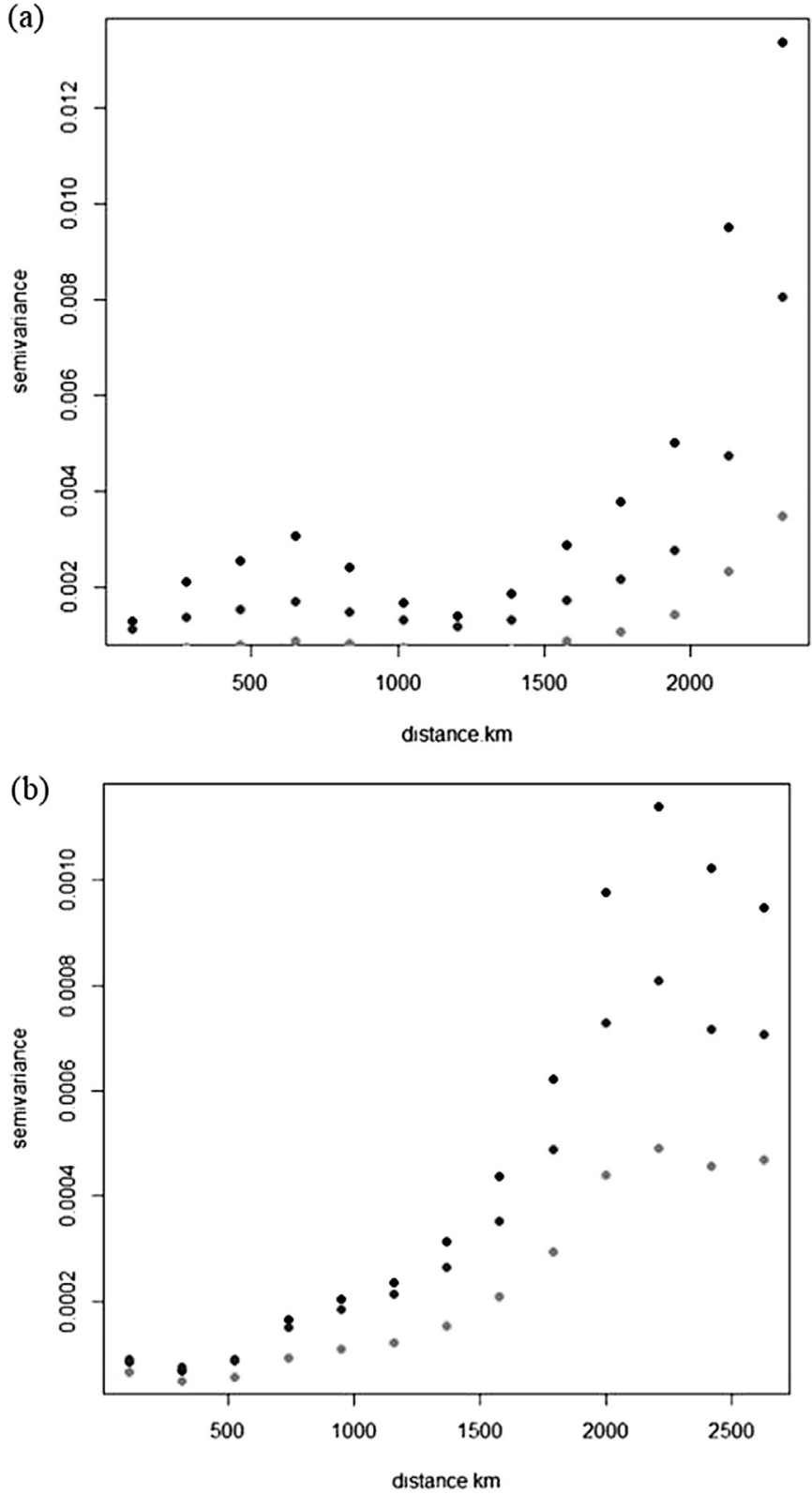

Fig. 9. Semivariance plotted as a function of distance $(\mathrm{km})$ for the dependent variable (black) and the residuals of both models (OLS in dark gray, middle, and GWR in light gray, bottom), for Southwestern Europe (a) and Southeastern Europe (b). The values of the GWR residuals for Southwestern Europe were multiplied by two in order to be visible at this scale.

Agricultural activities were also evidenced as significant factors of fire density. The dichotomous effect of goat and cattle density in fire occurrence, as seen in different areas in both regions, is a rather interesting result; on one hand, the use of fire as a tool for pasture renewal may increase fire density, which means this practice should be prevented and monitored more strictly. On the other hand, the grazing provided by livestock (cattle, goats) is a valuable vegetation management tool; in fact, the use of goats as "land cleaners" (Nunes, 2012) for example, can assume an important role in decreasing fuel loads in less accessible areas, including in mountainous regions, where other practices are difficult to apply.

Despite the continuing research studies and their importance to the management of fire-prone areas, a comprehensive assessment of fire occurrence at the European level is not yet available. This study is an additional step towards this goal, by exploring the spatial patterns of fire in a broad area, by identifying common and dissimilar features of fire distribution throughout the regions and by identifying the most significant factors of fire occurrence at local and regional levels, showing the possibility to adapt fire prevention strategies to the particular characteristics of the area.

\section{References}

Amatulli, G., Rodrigues, M. J., Trombetti, M., \& Lovreglio, R. (2006). Assessing longterm fire risk at local scale by means of decision tree technique. Journal of Geophysical Research: Biogeosciences (2005-2012), 111(G4).

Archibald, S., Nickless, A., Govender, N., Scholes, R. J., \& Lehsten, V. (2010). Climate and the inter-annual variability of fire in southern Africa: a meta-analysis using long-term field data and satellite-derived burnt area data. Global Ecology and Biogeography, 19(6), 794-809.

Archibald, S., Roy, D. P., van Wilgen, B. W., \& Scholes, R. J. (2009). What limits fire? An examination of drivers of burnt area in Southern Africa. Global Change Biology, 15(3), 613-630. http://dx.doi.org/10.1111/j.1365-2486.2008.01754.x.

Bistinas, I., Oom, D., Sá, A. C. L., Harrison, S. P., Prentice, I. C., \& Pereira, J. M. C. (2013) Relationships between human population density and burned area at Continental and global scales. PloS One, 8(12), e81188. http://dx.doi.org/10.1371/ journal.pone.0081188.

Bowman, D. M. J. S., Balch, J. K., Artaxo, P., Bond, W. J., Carlson, J. M., Cochrane, M. A et al. (2009). Fire in the Earth system. Science, 324(5926), 481-484. http:// dx.doi.org/10.1126/science.1163886.

Bravo, S., Kunst, C., Grau, R., \& Aráoz, E. (2010). Fire-rainfall relationships in Argentine Chaco savannas. Journal of Arid Environments, 74(10), 1319-1323. http://dx.doi.org/10.1016/j.jaridenv.2010.04.010.

Byrne, G., Charlton, M. E., \& Fotheringham, S. (2009). Multiple dependent hypothesis tests in geographically weighted regression. Retrieved from http://www. geocomputation.org/2009/PDF/Byrne_et_al.pdf.

Camia, A., Durrant-Houston, T., \& San-Miguel-Ayanz, J. (2010). The European fire database: development, structure and implementation. In Viegas (Ed.), VI International Conference on Forest Fire Research (pp. 1-8). Coimbra, Portugal.

Carmo, M., Moreira, F., Casimiro, P., \& Vaz, P. (2011). Land use and topography influences on wildfire occurrence in northern Portugal. Landscape and Urban Planning, $\quad 100(1-2), \quad$ 169-176. http://dx.doi.org/10.1016/ j.landurbplan.2010.11.017.

Carvalho, A., Flannigan, M. D., Logan, K. A., Gowman, L. M., Miranda, A. I., \& Borrego, C. (2010). The impact of spatial resolution on area burned and fire occurrence projections in Portugal under climate change. Climatic Change, 98(1-2), 177-197. http://dx.doi.org/10.1007/s10584-009-9667-2.

Carvalho, A., Monteiro, A., Flannigan, M. D., Solman, S., Miranda, A. I. I., \& Borrego, C. (2011). Forest fires in a changing climate and their impacts on air quality. Atmospheric Environment, 45(31), 5545-5553. http://dx.doi.org/10.1016/ j.atmosenv.2011.05.010.

Cary, G. J., Keane, R. E., Gardner, R. H., Lavorel, S., Flannigan, M. D., Davies, I. D., et al. (2006). Comparison of the sensitivity of landscape-fire-succession models to variation in terrain, fuel pattern, climate and weather. Landscape Ecology, 21(1), $121-137$.

Catry, F. X., Rego, F. C., Bação, F. L., \& Moreira, F. (2009). Modeling and mapping wildfire ignition risk in Portugal. International Journal of Wildland Fire, 18(8), 921-931.

Chuvieco, E., Aguado, I., Yebra, M., Nieto, H., Salas, P. J., Martín, M. P., et al. (2010). Development of a framework for fire risk assessment using remote sensing and geographic information system technologies. Ecological Modelling, 221(1), 46-58.

Chuvieco, E., Giglio, L., \& Justice, C. (2008). Global characterization of fire activity: toward defining fire regimes from Earth observation data. Global Change Biology, 14(7), 1488-1502. Retrieved from http://onlinelibrary.wiley.com/doi/ 10.1111/j.1365-2486.2008.01585.x/pdf.

Conedera, M., Torriani, D., Neff, C., Ricotta, C., Bajocco, S., \& Pezzatti, G. B. (2011). Using Monte Carlo simulations to estimate relative fire ignition danger in a lowto-medium fire-prone region. Forest Ecology and Management, 261(12), 21792187. Retrieved from http://www.sciencedirect.com/science/article/pii/ S0378112710004688.

Dormann, C., McPherson, J. M., Araújo, M. B., Bivand, R., Bolliger, J., Carl, G., et al. (2007). Methods to account for spatial autocorrelation in the analysis of species distributional data: a review. Ecography, 30(5), 609-628.

Drever, C. R., Drever, M. C., Messier, C., Bergeron, Y., \& Flannigan, M. (2008). Fire and the relative roles of weather, climate and landscape characteristics in the Great Lakes-St. Lawrence forest of Canada. Journal of Vegetation Science, 19(1), 57-66. http://dx.doi.org/10.3170/2007-8-18313.

Dwyer, E., Pinnock, S., Gregoire, J.-M., \& Pereira, J. M. C. (2000). Global spatial and temporal distribution of vegetation fire as determined from satellite observations. International Journal of Remote Sensing, 21(6-7), 1289-1302. http:// dx.doi.org/10.1080/014311600210182.

European Commission, J. R. C.. (2012). Forest fires in Europe, Middle East and North Africa (JRC Techni.)http://dx.doi.org/10.2788/58397.

EC, European Commission. (2012). Forest fires in Europe, Middle East and North Africa 2011. JRC Technical Reports. Report EUR 25483 EN, Italy.

EEA, European Environmental Agency. (2011). EEA reference grid. Available from http://www.eea.europa.eu/data-and-maps/data/ds_resolveuid/D63BFD626597-4D5F-BD35-9E06265102E0 Accessed in January 2012. 
EEA, European Environmental Agency. (2012). Biogeographical regions, Europe 2011. Available from http://www.eea.europa.eu/data-and-maps/data/ biogeographical-regions-europe.

EEA-ETC/TE, JRC. (2002). CORINE Land Cover update: IECLC2000 Project Technical Guidelines. August 2002

EUROSTAT. (2001). Degree of urbanisation. GISCO database (Geographic Information System of the European Commission). Available from http://epp.eurostat.ec. europa.eu/portal/page/portal/gisco_Geographical_information_maps/popups/ references/Population\%20Distribution\%20-\%20Demography Accessed in April 2010.

EUROSTAT. (2010). Regional Statistics. Available from http://epp.eurostat.ec.europa. eu/portal/page/portal/eurostat/home/ Accessed in April 2010.

FAO, Food and Agriculture Organisation of the United Nations. (2010). Global forest resources assessment 2010. Fao Forestry Paper 163. Rome, Italy.

Fernandes, P. M., Davies, M. T., Ascoli, D., Fernández, C., Moreira, F., Rigolot, E., et al. (2013). Prescribed burning in southern Europe: developing fire management in a dynamic landscape. Frontiers in Ecology and the Environment, 11(s1), e4-e14.

Flannigan, M. D., Cantin, A. S., de Groot, W. J., Wotton, M., Newbery, A., \& Gowman, L. M. (2013). Global wildland fire season severity in the 21st century. Forest Ecology and Management, 294, 54-61. http://dx.doi.org/10.1016/ j.foreco.2012.10.022.

Flannigan, M. D., Krawchuk, M. A., de Groot, W. J., Wotton, B. M., \& Gowman, L. M. (2009). Implications of changing climate for global wildland fire. International Journal of Wildland Fire, 18(5), 483-507. http://dx.doi.org/10.1071/WF08187.

Fotheringham, A. S., Brunsdon, C., \& Charlton, M. E. (2002). Geographically weighted regression: The analysis of spatially varying relationships (Vol. 13). Chichester: Wiley.

Gallego, F. J. (2010). A population density grid of the European Union. Population E' Environment, 31, 460-473.

Gallego, F. J., Batista, F., Rocha, C., \& Mubareka, S. (2011). Disaggregating population density of the European Union with CORINE land cover. International Journal of Geographical Information Science, 25(12), 2051-2069.

Ganteaume, A., Camia, A., Jappiot, M., San-Miguel-Ayanz, J., Long-Fournel, M., \& Lampin, C. (2013). A review of the main driving factors of forest fire ignition over Europe. Environmental Management, 51(3), 651-662. http://dx.doi.org/ 10.1007/s00267-012-9961-z.

Haylock, M. R., Hofstra, N., Klein Tank, A. M. G., Klok, E. J., Jones, P. D., \& New, M. (2008). A European daily high-resolution gridded data set of surface temperature and precipitation for 1950-2006. Journal of Geophysical Research, 113(D20119). http://dx.doi.org/10.1029/2008JD010201.

Heymann, Y. Steenmans, C., Croissille, G., \& Bossard, M. (1994). Corine land cover -Technical guide.

Jappiot, M., Gonzalez-Olabarria, J. R., Lampin-Maillet, C., \& Borgniet, L. (2009). Assessing wildfire risk in time and space. In Living with wildfires: What science can tell us. A contribution to the Science-Policy Dialogue. Discussion Paper 15 (European F.) (pp. 41-47).

Jarvis, A., Reuter, H. I., Nelson, A., \& Guevara, E. (2008). Hole-filled seamless SRTM data V4. 2008. International Centre for Tropical Agriculture (CIAT) 5.

Konstantinidis, P., Tsiourlis, G., \& Galatsidas, S. (2005). Effects of wildfire season on the resprouting of kermes oak (Quercus coccifera L.). Forest Ecology and Management, 208(1), 15-27.

Koutsias, N., Martínez, J., Chuvieco, E., \& Allgöwer, B. (2005). Modeling wildland fire occurrence in southern Europe by a geographically weighted regression approach. In J. de la Riva, F. Pérez-Cabello, \& E. Chuvieco (Eds.), Proceedings of the 5th International Workshop on Remote Sensing and GIS Applications to Forest Fire Management: Fire effects assessment (pp. 57-60). Zaragoza.

Koutsias, N., Martínez-Fernández, J., \& Allgöwer, B. (2010). Do factors causing wildfires vary in space? Evidence from geographically weighted regression. GIScience \& Remote Sensing, 47(2), 221-240.

Kupfer, J. A., \& Farris, C. A. (2006). Incorporating spatial non-stationarity of regression coefficients into predictive vegetation models. Landscape Ecology, 22(6), 837-852. http://dx.doi.org/10.1007/s10980-006-9058-2.

Legendre, P., \& Legendre, L. (2012). Numerical ecology (Vol. 20). Elsevier.

Leone, V., Lovreglio, R., Martín, M. P., Martínez, J., \& Vilar, L. (2009). Human factors of fire occurrence in the Mediterranean. In E. Chuvieco (Ed.), Earth observation of wildland fires in Mediterranean ecosystems (pp. 149-170). Berlin, Heidelberg: Springer Berlin Heidelberg. Retrieved from http://www.springerlink.com/ index/10.1007/978-3-642-01754-4_11.

Lindner, M., Maroschek, M., Netherer, S., Kremer, A., Barbati, A., Garcia-Gonzalo, J. et al. (2010). Climate change impacts, adaptive capacity, and vulnerability of European forest ecosystems. Forest Ecology and Management, 259(4), 698-709. http://dx.doi.org/10.1016/j.foreco.2009.09.023.

Martínez, J., Vega-García, C., \& Chuvieco, E. (2009). Human-caused wildfire risk rating for prevention planning in Spain. Journal of Environmental Management, 90(2), 1241-1252.

Mermoz, M., Kitzberger, T., \& Veblen, T. T. (2005). Landscape influences on occurrence and spread of wildfires in Patagonian forests and shrublands. Ecology, 86(10), 2705-2715. Retrieved from http://www.esajournals.org/doi/abs/10. $1890 / 04-1850$

Meyn, A., White, P. S., Buhk, C., \& Jentsch, A. (2007). Environmental drivers of large, infrequent wildfires: the emerging conceptual model. Progress in Physical Geography, 31(3), 287-312. http://dx.doi.org/10.1177/0309133307079365.

Montiel, C., \& San-Miguel-Ayanz, J. (2009). Policy analysis reveals the need for new approaches. In Living with wildfires: What science can tell us. A contribution to the Science-Policy Dialogue, European Forest Institute, Discussion Paper, 15 (pp. 63-67).
Montiel-Molina, C. (2012). Comparative assessment of wildland fire legislation and policies in the European Union: towards a Fire Framework Directive. Forest Policy and Economics. http://dx.doi.org/10.1016/j.forpol.2012.11.006.

Moreira, F., Vaz, P., Catry, F. X., \& Silva, J. S. (2009). Regional variations in wildfire susceptibility of land-cover types in Portugal: implications for landscape management to minimize fire hazard. International Journal of Wildland Fire, 18(5), 563-574. Retrieved from http://www.publish.csiro.au/paper/WF07098.

Moreira, F., Viedma, O., Arianoutsou, M., Curt, T., Koutsias, N., Rigolot, E., et al. (2011). Landscape-wildfire interactions in southern Europe: Implications for landscape management. Journal of Environmental Management, 92(10), 23892402. Retrieved from http://www.sciencedirect.com/science/article/pii/ S0301479711002258.

Moreno, J. M., Zuazua, E., Pérez, B., Luna, B., Velasco, A. \& de Dios, V. R. (2011) Rainfall patterns after fire differentially affect the recruitment of three Mediterranean shrubs. Biogeosciences, 8, 3721-3732.

Nunes, A. (2012). Regional variability and driving forces behind forest fires in Portugal an overview of the last three decades (1980-2009). Applied Geography, 34, 576-586.

Nunes, M. C. S., De Vasconcelos, M. J. P., Pereira, J. M. C., Dasgupta, N., Alldredge, R. J., \& Rego, F. C. (2005). Land cover type and fire in Portugal: do fires burn land cover selectively? Landscape Ecology, 20(6), 661-673. Retrieved from http:// www.springerlink.com/index/3WJ5U185QM432363.pdf.

Oliveira, S., Moreira, F., Boca, R., San-Miguel-Ayanz, J., \& Pereira, J. M. C. (2013) Assessment of fire selectivity in relation to land cover and topography: a comparison between Southern European countries. International Journal of Wildland Fire (Special issue).

Oliveira, S., Oehler, F., San-Miguel-Ayanz, J., Camia, A., \& Pereira, J. M. C. (2012) Modeling spatial patterns of fire occurrence in Mediterranean Europe using Multiple Regression and Random Forest. Forest Ecology and Management, 275 117-129. http://dx.doi.org/10.1016/j.foreco.2012.03.003.

Pausas, J. G. (2004). Changes in fire and climate in the eastern Iberian Peninsula (Mediterranean basin). Climatic Change, 63(3), 337-350.

Pechony, O., \& Shindell, D. T. (2010). Driving forces of global wildfires over the past millennium and the forthcoming century. Proceedings of the National Academy of Sciences, 107(45), 19167-19170.

Pereira, M. G., Trigo, R. M., Dacamara, C. C., Pereira, J., \& Leite, S. M. (2005). Synoptic patterns associated with large summer forest fires in Portugal. Agricultural and Forest Meteorology, 129(1), 11-25.

Platts. (2006). McGraw-Hill Research and Analytics, USA. Available from http://www platts.com/Products/gisdata Accessed in May 2010.

R Development Core Team. (2011). R: A language and environment for statistical computing. Vienna, Austria: R Foundation for Statistical Computing, ISBN 3 900051-07-0. Available from http://www.R-project.org/ Accessed in May 2011.

Reuter, H. I., Nelson, A., \& Jarvis, A. (2007). An evaluation of void-filling interpolation methods for SRTM data. International Journal of Geographical Information Science, 21(9), 983-1008.

Roekaerts, M. (2002). The biogeographical regions map of Europe. EEA report no $1 /$ 2002 "Europe's biodiversity: biogeographical regions and seas". Copenhagen: European Environmental Agency. Available from http://dataservice. eea. eu. int/ dataservice Accessed in May 2011.

Romero-Calcerrada, R., Barrio-Parra, F., Millington, J. D. A., \& Novillo, C. J. (2010). Spatial modelling of socioeconomic data to understand patterns of humancaused wildfire ignition risk in the SW of Madrid (central Spain). Ecological Modelling, 221(1), 34-45.

Romero-Calcerrada, R., Novillo, C. J., Millington, J. D. A., \& Gomez-Jimenez, I. (2008). GIS analysis of spatial patterns of human-caused wildfire ignition risk in the SW of Madrid (Central Spain). Landscape Ecology, 23(3), 341-354. http://dx.doi.org 10.1007/s10980-008-9190-2.

Sá, A. C. L., Pereira, J. M. C., Charlton, M. E., Mota, B., Barbosa, P., \& Stewart Fotheringham, A. (2011). The pyrogeography of sub-Saharan Africa: a study of the spatial non-stationarity of fire-environment relationships using GWR Journal of Geographical Systems, 13(3), 227-248. http://dx.doi.org/10.1007/ s10109-010-0123-7.

San-Miguel-Ayanz, J., \& Camia, A. (2009). Forest fires at a glance: facts, figures and trends in the EU. In Living with wildfires: What science can tell us. EFI Discussion Paper, 15 (pp. 11-18).

San-Miguel-Ayanz, J., Carlson, J. D., Alexander, M., Tolhurst, K., Morgan, G., \& Sneeuwjagt, R. (2003). Current methods to assess fire danger potential. In E. Chuvieco (Ed.), Wildland fire danger estimation and mapping - The role of remote sensing data (pp. 21-62). World Scientific Publishing.

San-Miguel-Ayanz, J., Moreno, J. M., \& Camia, A. (2013). Analysis of large fires in European Mediterranean landscapes: lessons learned and perspectives. Forest Ecology and Management. http://dx.doi.org/10.1016/j.foreco.2012.10.050.

San-Miguel-Ayanz, J., Pereira, J. M. C., Boca, R., Strobl, P., Kucera, J., \& Pekkarinen, A (2009). Forest fires in the European Mediterranean region: Mapping and analysis of burned areas. Berlin, Germany: Springer-Verlag.

San-Miguel-Ayanz, J., Schulte, E., Schmuck, G., Camia, A., Strobl, P., Liberta, G., et al. (2012). Comprehensive monitoring of wildfires in Europe: the European forest fire information system (EFFIS). In J. Tiefenbacher (Ed.), Approaches to managing disaster-Assessing hazards, emergencies and disaster impacts (pp. 87-108). InTech.

Sebastián-López, A., Salvador-Civil, R., Gonzalo-Jiménez, J., \& San-Miguel-Ayanz, J. (2008). Integration of socio-economic and environmental variables for modelling long-term fire danger in Southern Europe. European Journal of Forest Research, 127(2), 149-163. 
Syphard, A. D., Radeloff, V. C., Keuler, N. S., Taylor, R. S., Hawbaker, T. J., Stewart, S. I., et al. (2008). Predicting spatial patterns of fire on a southern California landscape. International Journal of Wildland Fire, 17(5), 602. http://dx.doi.org/ 10.1071/WF07087.

Tele Atlas NV and Tele Atlas North America. (2007). Tele Atlas MultiNet_Version 3.4.2.1 Data Specification.

Trigo, R. M., Pereira, J. M. C., Pereira, M. G., Mota, B., Calado, T. J., Dacamara, C. C. et al. (2006). Atmospheric conditions associated with the exceptional fire season of 2003 in Portugal. International Journal of Climatology, 26(13), 1741-1757. http://dx.doi.org/10.1002/joc.1333.

Vasilakos, C., Kalabokidis, K., Hatzopoulos, J., \& Matsinos, I. (2008). Identifying wildland fire ignition factors through sensitivity analysis of a neural network Natural Hazards, 50(1), 125-143. http://dx.doi.org/10.1007/s11069-008-9326-3.
Vilar, L., Nieto, H., \& Martín, M. P. (2010). Integration of lightning-and humancaused wildfire occurrence models. Human and Ecological Risk Assessment: An International Journal, 16(2), 340-364.

Vilar, L., Woolford, D. G., Martell, D. L., \& Martín, M. P. (2010). A model for predicting human-caused wildfire occurrence in the region of Madrid, Spain. International Journal of Wildland Fire, 19(3), 325-337.

Wang, Q., Ni, J., \& Tenhunen, J. (2005). Application of a geographically-weighted regression analysis to estimate net primary production of Chinese forest ecosystems. Global Ecology and Biogeography, 14(4), 379-393.

Whelan, R. J. (1995). The ecology of fire. Cambridge University Press.

Wright, K. (2011). corrgram: Plot a correlogram. R package version 1.1. Available from http://CRAN.R-project.org/package=corrgram Accessed in January 2012. 